prolonged. Left pectoral shorter and much weaker than the right. Upper eye in advance of lower. Scales edged with 10 (circa) spikelets. Color (recent) grey, blotched with black, black vertical bars at regular intervals on the dorsal and anal ; left side white, with a purple blush, orange spots, and the fins orange.

Long.

Loc.-Moreton Bay.

\title{
Crossorhinus.
}

Under the common name of "Tiger Shark," two fish commonly associated in habitat, seem to be considered by Queensland fishermen as varieties of one and the same. One of these is certainly Crossrhinus barbatus, and the other does not appear to have been as yet discriminated by ichthyology. It is in the style of colouring, a matter too much neglected in describing these sharks, allied to C. tentaculatus. Pet., but differs from that species as characterised by possessing the tentacular fringe of barbatus. It is a much smaller fish than barbatus, never apparently exceeding three feet in length, whereas six, ten, and twelve feet are attained by the latter.

\section{C. ornatus.}

Tentacles as in $C$. barbatus. Distance between the dorsals less than the length of either. No supraciliary tubercles; fifth gill opening nearly twice as long as the fourth. Color yellowish, with broad dark cross bands, the hinder ones encircling the tail. The two dorsal bands have deeply fretted edges, and enclose pairs of ocelli. On the snout, a pair of dendritic brown markings. On the occiput, a symmetrical brown pattern, and between each of the caudal zones is a black spot.

Loc.-Moreton Bay, \&c.

Occasional Notes on Plants Indigenous in the immediate Neighbourhood of Sydney. No. 4.

By E. Haviland.

I suppose there are few persons, who, having rambled about the coast in the neighbourhood of Sydney, have not become acquainted with a shrub or small tree, ranging from two to six or eight feet 
high ; and bearing a profusion of white flowers, which, at a distance have the appearance of almond or apple blossoms. It is the large variety of Leptospermum flavescens. The genus Leptospermum belongs to Myrtacea; perhaps our most valuable order. Dr. Woolls has enumerated eight species indigenous in the County of Cumberland; but the genus extends from Victoria and Tasmania on the south to Port Denison on the north. In the immediate neighbourhood of Sydney, however, I have most frequently met with $L$. flavescens and its numerous varieties, and $L$. attenuatum. The former seeking comparatively dry and stony localities, while the latter rejoices in the margins of creeks, with its roots almost in water. Like the Lobelias, the species of this genus are exceedingly difficult to identify. Bentham, in referring to this difficulty, says, "The whole of those with five celled ovaries, different as some of them appear at first sight, pass so gradually, the one into the other, that they might readily be admitted as varieties of one species." Of L. flavescens, he adds, that "It is scarcely to be distinguished from $L$. lanigerum, except by the absence of hairs or down," and that " the extreme forms of either one or the other, are so dissimilar, that it requires the examination of a large number of specimens to believe in their specific identity." My attention was first directed, in a special way, to this genus, by the apparent absence in many otherwise perfect flowers, of the style and stigma, especially was this the case in L. attenuatum. Knowing that the genus was neither monœcious or diœcious ; I was certainly astonished to find many flowers with stamens only, until, after a more careful examination, I found that in several the style and stigma had, from some cause, withered as soon as formed, and appeared only as a small black spec (as though scorched) on the top of the ovary. In other flowers, although the stamens and anthers were fully formed ; the stigma, still healthy, was but a mere speck sessile on the ovary. The stamens, of which there are about thirty in each flower in this genus, being so curved inwards, that the anthers were immediately over the stigma. In other flowers, I found the style and stigma in so many different stages, and the relative positions of the stamens and pistils so different as they 
progressed in their growth, and yet these differences so uniform, that I felt satisfied that some special purpose was to be effected by them. Taking therefore the larger species, L. flavescens, I have examined very carefully, and without removing them from the plants, a great number of flowers ; taking notes in almost every instance for comparison with each other. I have also examined a great many flowers at home microscopically; perhaps therefore I cannot do better than to read two or three of these notes. I have selected those that will best shew the progressive stages through which the organs of fertilisation of the plant pass. As in these notes I make use of the word, cup, I may explain, that in this genus, the calyxtube is adnate with the ovary, but rising somewhat above it, while the top of the ovary is itself a little depressed, a hollow cone or cup is formed; round the edges of which, but on the margin of the disk, the stamens are arranged, with the style rising from the depression in its centre. I may also say, that the whole of my notes could be arranged in groups similar to that I now read.

Note No. 1.-Stamens all perfect and bent over the stigma, Anthers not yet open. Stigma scarcely formed; being a mere speck sessile upon the ovary.

No. 2.-Stamens perfect. Anthers fully developed and apparently ready to open; all bent over the stigma. Style scarcely a quarter of a line high. Stigma very small, not the tenth of a line wide.

No. 3.-Stamens perfect ; bent over the stigma. Anthers seem almost bursting. Style half a line high. Stigma wider than in number two, but far from maturity.

No. 4.- Stamens all perfect, but much more erect than in number three. Anthers open, but retaining their pollen. Style a line high. Stigma still small; but becoming somewhat peltate.

No. 5,-Stamens perfect; all erect but five, which are still bent over the stigma. The anthers of the erect stamens open; those of the bent ones still closed. Style one and a-half lines high. Stigma broad and peltate, but not mature. Some loose pollen in the cup, round the base of the style. 
No. 6.-The stamens perfect; all quite erect but three, most of those erect, open. The three stamens not erect, are bent down inside the cup, so that the anthers are below the stigma. The anthers of these are also open, and there is a considerable amount of pollen in the cup; but none on the stigma. Style two lines high. Stigma broad and peltate, but not mature.

No. 7. - Stamens all reflexed but two, i.e., bent outwardly from the flower; and many of the anthers empty; those not reflexed are so bent down that the anthers are below the stigma. Style exceeding two lines high. Stigma mature and viscid. No pollen either in cup or on the stigma.

No. 8. - Stamens all reflexed, most of them withered ; those still perfect have the anthers quite open, and exposing the ripe pollen. None of this pollen can possibly fall on the stigma. Still there is pollen upon the stigma, which is large, mature and very viscid.

No. 9.-Stamens all reflexed, most of them spreading out across the petals and away from the centre of the flower; many of them withered. Anthers all empty but one. Style three lines high. Stigma broadly peltate and very viscid. Some pollen in the cup, and a few grains on the stigma.

In addition to these, I found, after carefully searching another plant, three flowers which I considered required careful watching. In ore of them, five of the stamens with fully ripe pollen, were bent so directly over the stigma, which was also near maturity, as to lead me to expect a case of self-fertilization. In another flower one stamen was left, not only not reflexed; but with the anther burst and pressing upon the fully mature and viscid stigma. In a third flower, seven of the stamens, with the anthers fully mature, but not open, impended directly over the stigma, which was mature and viscid. These three flowers I marked A, B and C, by my usual plan of attaching very small tin labels to them. In A, having five stamens, with the anthers fully mature, bent over the nearly mature stigma; I found, on the second day, that two of the stamens had become reflexed; and were hanging with others over the outside of the flower. The remaining three were bent down inside the flower, so that the anthers were below the stigma and 
could not fertilize it. B was in much the same state as on the preceding day; the single stamen, with its open anther, still pressing on the stigma. $\mathrm{C}$, in which the seven stamens impended over the mature stigma, had the whole of these stamens reflexed, but the anthers still closed. B, therefore was the only one requiring further attention. Three days afterwards, I re-examined this flower and found the filament of the stamen withered; the stigma mature and bearing pollen from the anther of its own flower. This pollen could not easily be brushed off. A proof, I think, that some of the pollen tubes had already penetrated the stigma. I took this flower home, and with a microscope power of 300 diameters, could distinctly trace the pollen tubes for some little distance, but could not follow them into the ovary; still there can be no doubt, that if I had left this flower on the plant, it would have been self-fertilized. I have also, as I have already mentioned, found in some cases, pollen in the bottom of the cup, at the base of style; showing that occasionally the anthers shed their pollen after the stamens have become erect, but before they are reflexed; and as I have sometimes found very small apterous insects also in the cup amongst this pollen, and loaded with it; I have no doubt that it is occasionally conveyed by them to the stigma of the same flower. I may say that although what I have written refers more especially to L. flavescens and L. attenuatum, yet, from what I have seen of the other species, I think it will equally apply to the whole genus

The impression made upon my mind, with regard to this genus, is, that, as a rule, the plant must be cross-fertilised. This crossfertilisation being brought about by two means. First, by the difference in the times of maturing of the anthers and the stigma, and secondly, by the change in their relative positions. For I think that these notes show, that even after the stamens and anthers are perfectiy formed, the stigma is very far from maturity, often indeed but a mere speck upon the ovary. That as the style lengthens and the stigma takes its proper hollow-peltate form, and becomes mature and viscid; so the anthers avoid it by the stamens becoming first erect and then reflexed or bent quite away from it. 
Nevertheless, as occasionally one or two of the stamens fail to leave their first position, remaining still over the stigma till both it and the anthers are mature; and especially as this flower seems to be the favourite resort of the insects I have alluded to, and which may carry pollen from the cup to the stigma; I have no doubt that self-fertilisation occasionally takes place.

In concluding this paper, I should like to add a word of caution, for the benefit of young botanists who may perchance read it; and who may feel inclined to study this matter of fertilization. Neither in this or in any other question of physiological or structural botany, should undue reliance be placed on the examination of cultivated plants ; and even in the case of collected wild flowers, great care is necessary to avoid being misled. Most plants are more or less altered by cultivation. Petals are gained by the sacrifice of stamens; and varieties are produced, which in a great measure destroy typical specific forms. I need only refer to the vast difference between the wild and the garden rose. The first with its five petals and numerous stamens; the second with its numerous petals and, if the gardener can help it, no stamens. With regard to collected wild flowers; of course they must be eollected for microscopic or inome study; but it will very often be found that those whose stamens assume any one position relatively to the stigma while on the plant, have that position quite changed, by the drying and contortion of the filaments very soon after they are collected. It is on that account that I have been careful to study the Leptospermums in situ. To arrive at a correct conclusion of any matter touching the physiology and habits of plants, they must be studied in their own homes.

Localities of some species of hecent Polynesian Mollusca

$$
\text { By J. Brazier, C.M.Z.S., \&c. }
$$

1. Pirenopsis costata.

Melania costata, Quoy and Gaimard (non Reeve), Voy. de l' Astr. Zool. Vol. 3, p. 155, pl. 56, fig. 34-37. Melasma costata, H. \& A. Adams, Recent Mollusca, Vol. 2, p. 302. Chenu. 


\section{$2 \mathrm{BHL}$ Biodiversity Heritage Library}

Haviland, E. 1883. "Occasional notes on plants indigenous in the immediate neighbourhood of Sydney. No. 4." Proceedings of the Linnean Society of New South Wales 8, 289-294. https://doi.org/10.5962/bhl.part.28657.

View This Item Online: https://www.biodiversitylibrary.org/item/30993

DOI: https://doi.org/10.5962/bhl.part.28657

Permalink: https://www.biodiversitylibrary.org/partpdf/28657

\section{Holding Institution}

MBLWHOI Library

\section{Sponsored by}

MBLWHOI Library

\section{Copyright \& Reuse}

Copyright Status: NOT_IN_COPYRIGHT

This document was created from content at the Biodiversity Heritage Library, the world's largest open access digital library for biodiversity literature and archives. Visit BHL at https://www.biodiversitylibrary.org. 